\title{
Decadal Modeling (2004-2021) Ecosystem Recovery Impacted by Mount Semeru Eruption Volcanic Activities using Vegetation Succession as a Proxy in the Lava Flow Stream
}

\author{
Andri Wibowo \\ Universitas Indonesia. Pondok Cina, Beji, Depok City, West Java 16424
}

* Corresponding author : paleobio2020@gmail.com

\begin{abstract}
Volcano eruptions undoubtly cause environmental impacts and damages. After the eruption, there will be vast barren land that was previously fertile ground covered by vegetation and tree line. Lava from an eruption will flow to the land via a river stream, destroying everything in its path, including vegetation. While the ecosystem actually has an ability to recover. The natural process of ecosystem recovery is related to the succession of vegetation. Then this study aims to assess and model how the ecosystem can recover and how the vegetation can respond to the damage caused by Semeru, one of the most powerful volcanic eruptions on Java island. The study areas were 2 regions that had been impacted by the Semeru lava flow for the period of 2004-2021. Based on the results, the ecosystem recovery of Semeru post-eruption was achieved within 5 years. During this time, the vegetation succession rate, as measured by vegetation cover, increased nearly ten folds. The post-eruption ecosystem recovery was indicated by the ecosystem transformation from a damaged ecosystem indicated by a lava-dominated surface to one with the presence of vegetation and hardened lava. The recovered ecosystem in Semeru's posteruption was composed of solid lava covers (39\%), liquid lava (34\%), and vegetation covers (27\%).Then, the presence of vegetation and its succession rate can be used as a proxy of ecosystem recovery after a vast volcanic eruption.
\end{abstract}

Keywords: eruption, recovery, Semeru, succession, vegetation

\section{Introduction}

\subsection{Volcano and vegetation succession}

Geologists, zoologists, and botanists visiting the area years after the eruption documented the colonization of the nearly sterilized remains in great detail. Three years after the eruption, twenty-six species, mostly ferns and algae, had been identified. Eleven years later, grass and the first tree, Casuarina equisetifolia, appeared (Potgieter et al 2014). The grasses quickly replaced the ferns, resulting in a savannah ecosystem. Around 1906, an increasing number of trees began to replace the grass-savannah. Krakatoa's ruins were once again covered by dense tropical jungle twenty years later. In 1927, a new island appeared in the caldera formed by the former volcano's collapse. Anak Krakatau, or Krakatoa's child, stands 980 feet tall today. The ongoing activity of the volcanic mountain prevented until now the growth of a jungle apart some sparse fig trees near its shoreline.

Prior to the eruption, the area around Mount St. Helens (Del Moral et al 1995) was home to nearly 286 plant species. Twenty surviving species were counted in the first year after the eruption. The Fireweed (Epilobium angustifolium), Creeping Thistle (Circum arvense), and Broadleaf Lupine were the most common species (Lupinus latifolius). All of the surviving species were geophytes, which are plants with specialized tissue capable of regeneration that are hidden underground, such as bulbs, tubers, or corms. Aside from the survivors, seeds of newly arrived plants were carried into the blast zone by wind or animals wapitis. Botanists discovered 75 new species in 1989 and 156 new species were discovered in 1994.

Ongoing research on newly generated or recently devastated land by a volcano has revealed that nature quickly rebounds from a disaster and that plants have surprising mechanisms for colonizing new territory. Nobody anticipated plant life to return so soon in the St. Helens blast zone. Some bulbs were shielded by late May snow, and the regenerated plants offered the first spots where other seeds, carried by animals and wind, could germinate safely. Wandering elk hooves helped to break up the volcanic deposits' hard surface, allowing water to permeate and seed to find an ecological niche. Seabird colonies on volcanic islands are a hotspot for plants; the birds disseminate seeds from the mainland, but their feces enrich the newly formed soil. To put it another way, life finds a way.

\subsection{Lava flow stream}

Lava flows (Kilburn 2000) are the most common type of volcanic feature on the planet. Lavas are excellent building materials as well as an important source of nutrients for future agricultural soils. Nonetheless, lavas continue to pose a threat to human activity. Lava flow is known to cause a stream with significant consequences along its path. On Tuesday, March 21, in the foothills of Mount Vesuvius, Italy, lava streams from a new eruption had descended the volcano's flanks and crept through the village, slowly and inexorably eating their way from one building to the next in less than 48 hours.

Lava flow streams are molten rock, or magma, outpourings. On earth, the vast majority have silicate compositions, with common melting temperatures ranging from $800{ }^{\circ} \mathrm{C}$ to $1200{ }^{\circ} \mathrm{C}$; lava of sulphur, as seen in Japan's Siretoko-Iosan volcano and Chile's Lastarria volcano; and lava of carbonate compositions, as seen in Tanzania's Ol Doinyo Lengai volcano.

The extreme elongation downslope distinguishes lava flow streams from lava domes. Historically, the volumes produced by single lava effusions ranged from minor dribbles to outpourings of a few cubic kilometers, as seen on Etna in Sicily (years 1614-24), Lanzarote in the Canary islands (years 1730-36), and Lakagigar in Iceland (year 1783-85). The resulting flow fields can span tens of kilometers, span kilometers, and reach thicknesses of hundreds of meters, though most are much smaller. The durations of single eruptions also vary greatly, and while some can last decades, the vast majority last only a few days or months. Flow lengthening rates rarely exceed a brisk walking pace, allowing people to usually escape the immediate lava flow streams (Deligne et al 2010, Ely et al 2012). 


\subsection{Mount Semeru volcanic activity history}

The monitoring records confirmed volcanic activity at Mount Semeru in 1990, 1992, 1994, 2002, 2004, 2005, 2007, and 2008. In 2008, several eruptions were recorded, from May 15 to May 22, 2008. Based on observations in 2004, the volcano released lava flows into the Besuksemut river and resulted in lava flow streams impacting everything along its course and reaching a distance of more than $10 \mathrm{~km}$ to the downstream areas. Considering the volcanic activity of Semeru, then it is important to assess and model how the lava flow originated in its surrounding ecosystem and how the ecosystem responded to it. The ecosystem responses were assessed using vegetation succession as the proxy as currently was hypothesized (Whittaker et al 1989).

\section{Methods}

\subsection{Study area and ROI}

The study area was the Besuksemut river stream, which originated from Mount Semeru. The width of the Besuksemut river varied from $30.11 \mathrm{~m}$ to $439.07 \mathrm{~m}$. Varieties of this river width were influenced by the previous lava flow that had eroded the intact river banks.

The Region of Interest (ROI) in this research was two locations within streams of lava flow. This stream was developed due to the frequent lava flow of Mount Semeru within the current river stream of Besuksemut. The first ROI was located at $8^{\circ} 10^{\prime} 12.3^{\prime \prime} \mathrm{S}$ and $112^{\circ} 59^{\prime} 40.4^{\prime \prime} \mathrm{E}$, located $9.85 \mathrm{~km}$ from the Semeru crater. While the second ROI was located at $8^{\circ} 11^{\prime} 08.2^{\prime \prime} \mathrm{S}$ and $113^{\circ} 01^{\prime} 33.9^{\prime \prime} \mathrm{E}$, located $13.48 \mathrm{~km}$ from the Semeru crater.

\subsection{Vegetation assessments}

Vegetation assessments within the Besuksemut river stream in ROI 1 were conducted following Ishaq et al (2020) and implemented from 2004. Observation plots were selected for assessing the distribution of pioneer vegetation in various locations within Besuksemut streams. Assessment of vegetation was carried out on all types of vegetation in various growth stages, including seedlings, saplings, poles, and trees. Vegetation assessment plots were nested within a $10 \times 10 \mathrm{~m}$ main plot, and the geo coordinate of each plot was registered using GPS. The geo coordinate database of vegetation assessments was then mapped using GIS to develop the vegetation layer.

\subsection{Ecosystem assessments}

The assessed ecosystem within Besuksemut streams in ROI 2 impacted by the Semeru volcanic activity included the vegetation covers, hard and soft lava. Hard lava was lava that was hardened and forming sediment. Soft lava was lava that had not yet formed sediment and was still being influenced by water streams. The vegetation covers, hard, and soft lava were classified using Geographical Information System (GIS) methods with ArcView 3.2 (Thoha and Triani 2021). The method starts with the retrieval of the Besuksemut stream boundary and Landsat 8 Operational Land Imager (OLI) images of this stream with a spatial resolution of $30 \mathrm{~m}$ per pixel. The Landsat 8 OLI imagery of the stream is then classified into vegetation covers, hard, and soft lava (Utami et al 2017). The result is a thematic layer in the form of shape files (shps) of Besuksemut streams.

\section{Results and Discussion}
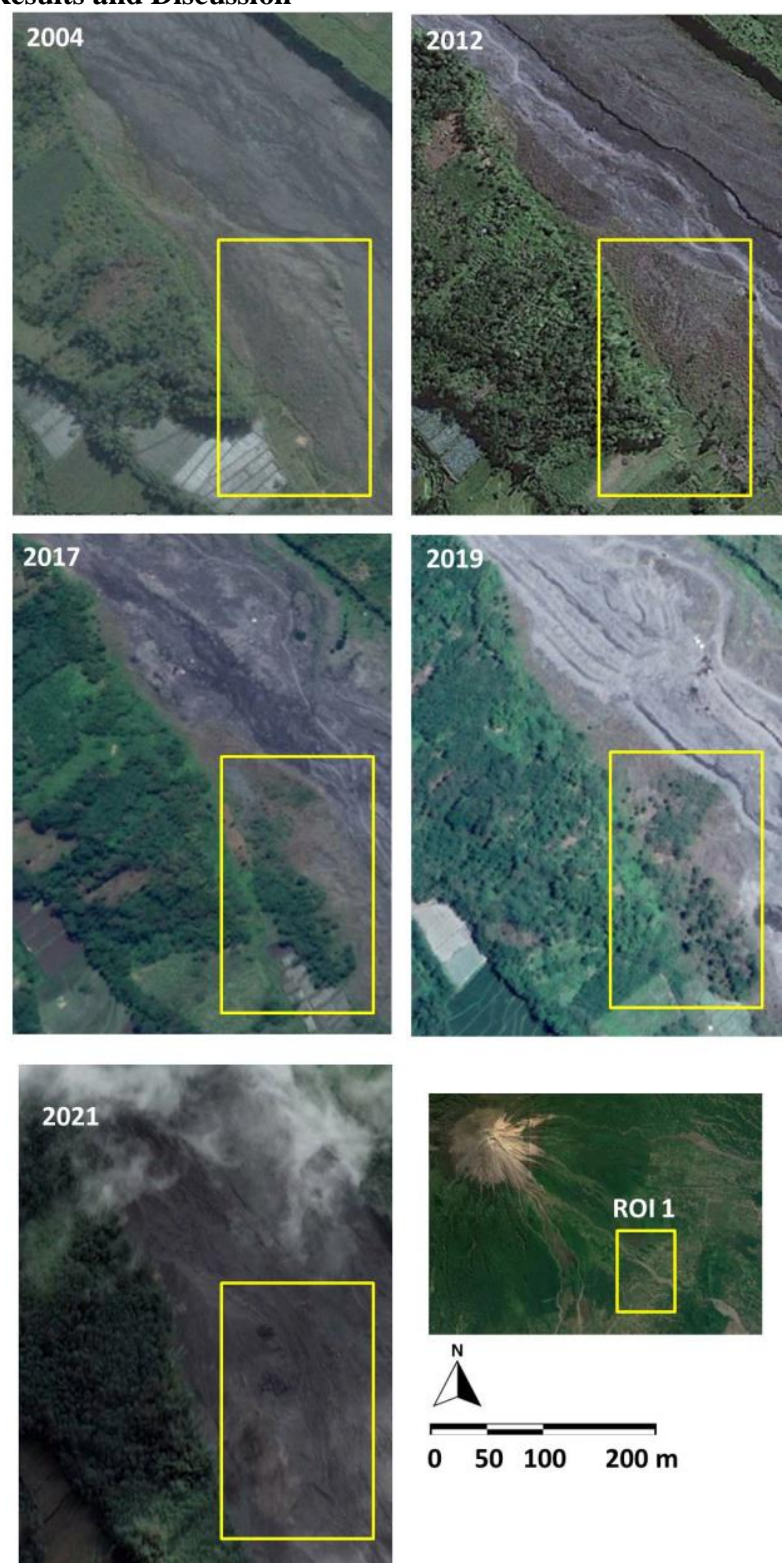

Fig 1 Vegetation succession in ROI 1 (yellow triangle) within Besuksemut river lava flow stream (2004-2021) (Background: Google Earth/Copernicus/Landsat/Maxar)

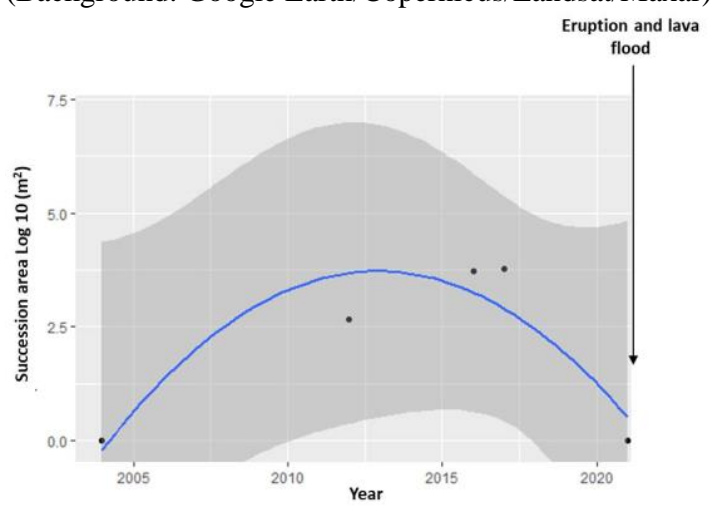

Fig 2 The trends of vegetation succession areas $\left(\log 10 \mathrm{~m}^{2}\right)$ with $95 \%$ CI for shaded area in ROI 1 within Besuksemut streams

The ROI 1 was a part of the Besuksemut river located $9.85 \mathrm{~km}$ from the Semeru crater and had a width of $200 \mathrm{~m}$. This part was inundated by lava flowing from Semeru crater. 
How the ecosystem responded to the Semeru eruption and lava can be seen in Figure 1. In 2004, these parts of the rivers were inundated by thick lava. The lava was accumulated, forming a hard sediment, providing a hard surface, and media. This sediment lava developed on the right and left sides of the river since the middle parts of the river were still receiving water streams and lava. Since 2012, a patch of vegetation cover consisting of grass and bush has been observed near the river bank on the top of sediment lava layers. Within 5 years or in 2017, the abrupt increases in vegetation cover were observed. Predominantly, the layer of grass that covered it was replaced by a thick layer of bushes. The vegetation cover kept increasing in 2019 as tall vegetation was observed. However, the vegetation succession was hindered when an eruption and lava flood occurred again in 2021 and inundated the vegetation cover. The trends of vegetation succession can be observed in Figure 2. Based on the trends, the ecosystem recovery of Semeru post-eruption was achieved within 5 years. The succession rate was delayed in the several years after 2004 before increasing sharply. The decrease and delay in rate of vegetation succession and relative stagnation was probably caused by poor soil conditions and limited influx of seeds of new plant species (Magnusson et al 2014).
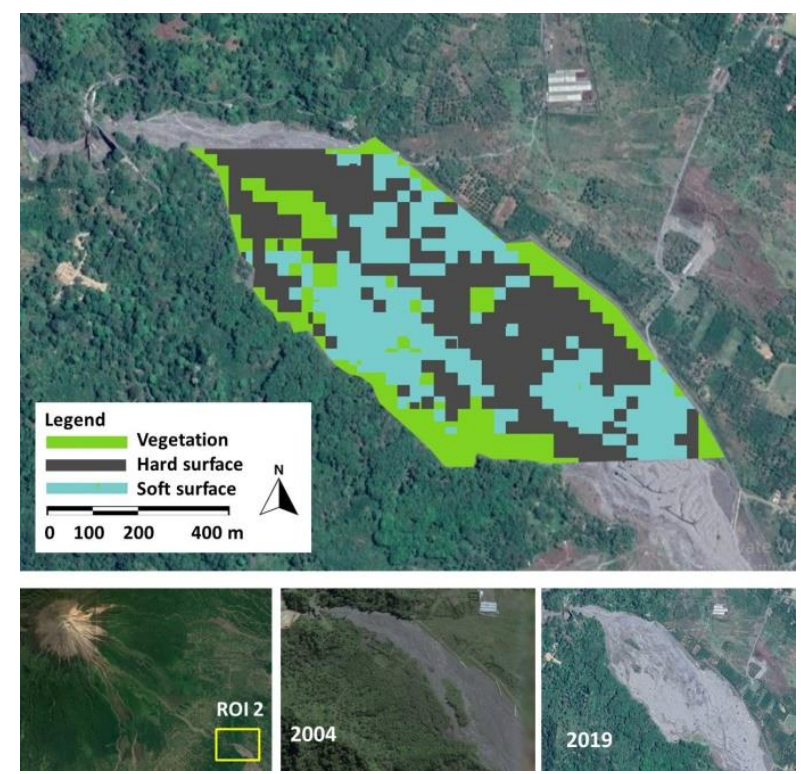

Fig 3 Model of vegetation succession areas in ROI 2 above lava covers and hard surfaces within Besuksemut streams (Background: Google Earth/Copernicus/Landsat/Maxar)

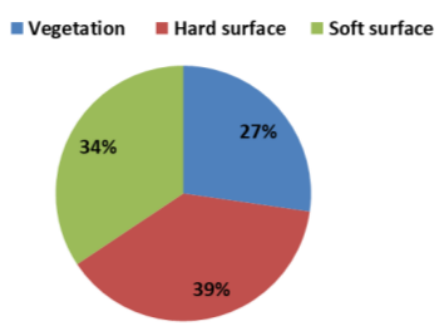

Fig 4 Composition of vegetation covers, hard, and soft surfaces in ROI 2 within Besuksemut streams

An impacted ecosystem by volcanic eruption consists of vegetation covered, hard sediment lava, and a soft surface that is a mix of lava flow and water. ROI 2 is part of the Besuksemut stream, located $13.48 \mathrm{~km}$ from the Semeru crater. In 2004, this part was struck by lava flow and, as a result, the river bank on the west side, sized at $146,157 \mathrm{~m}^{2}$ or $1.11 \mathrm{~km} \times 166.82 \mathrm{~m}$, has been eroded and missing due to lava flow.

In 2019, the ecosystem in this part has changed. The ecosystem has been changed from lava mixed with waterdominated covers to combinations of vegetation covers, hard sediment lava, and soft surface. The vegetation covers (Figure 3) were observed in the northern parts of the inlet and on the river banks on the east and west sides. Actually, the vegetation succession patterns were following the hardened lava cover patterns. The absence of vegetation in the middle of riverbeds is due to the sand mining activities in this part.

After the succession process, the compositions of this impacted ecosystem were dominated by hardened lava, lavawater mixtures, and vegetation cover (Figure 4).The presence of vegetation indicates the results of successions within an impacted ecosystem influenced by lava from volcanic eruptions. The results of this study regarding the presence of vegetation were in agreement with other studies. Similar to our result, Ishaq et al. (2020) confirmed the presence of vascular plant species $P$. rigida that developed well in the lava flow deposits, including layers of sand and gravel in the riverbeds. The vegetation successions were derived from vegetative reproduction throughout the volcanic deposits. Vegetative reproduction plays a major role in increases in cover.

The presence of vegetation in Besuksemut streams was related to seed dispersal. Most plants can be dispersed by winds and even flower visitors including ants, bugs, a butterfly, and a fly from nearby forests. In fact, the Besuksemut streams were surrounded by primary and secondary forests that may contribute to the vegetation succession within Besuksemut streams.

In this study, it is estimated that the vegetation succession rate after the eruption was 5 years. The post-eruption succession can take a long time. According to Abe (2009), the succession rate on Nishino-shima Island after a volcano eruption takes ten years. It is estimated that the vegetation succession rate was 0.10 species per year.

The patterns of vegetation succession on ROI were varied, with more vegetation cover observed near the inlet and river banks. According to Tsuyuzaki (1995), ground surface movements strongly restricted increases in plant cover and the distance from source vegetation was the principal determinant of plant density and cover. Because of differences in disturbance intensity, successional rates were higher in stable substrates outside gullies and lower in some gullies on exposed original topsoil.

\section{Conclusions}

Over the first 20 years, ecosystems of Semeru volcano has been impacted and damaged by lava flow originated from Semeru. Based on the results, the ecosystem recovery of Semeru post-eruption was achieved within 5 years. During this time, the vegetation succession rate, as measured by vegetation cover, increased nearly ten folds. The posteruption ecosystem recovery was indicated by the ecosystem transformation from a damaged ecosystem indicated by a lava-dominated surface to one with the presence of vegetation and hardened lava. The recovered ecosystem in Semeru's post-eruption was composed of solid lava covers $(39 \%)$, liquid lava (34\%), and vegetation covers (27\%).Then, the presence of vegetation and its succession rate can be used as a proxy of ecosystem recovery after a vast volcanic eruption. 


\section{References}

Abe T 2009. Colonization of Nishino-shima Island by Plants and Arthropods 31 Years after Eruption. Pacific Science. 355-365.

Deligne N, Conrey R, Cashman K, Grant G, Amidon W 2010 Lava flows vs. surface water: the geologic battle for the upper McKenzie valley, central Oregon Cascades. AGU Fall Meeting Abstracts.

Del Moral R, Titus J, Cook A 1995 Early primary succession on Mount St. Helens, Washington, USA. Journal of Vegetation Science. 6. 107 - 120.

Ely L, Brossy C, House P, Safran E, et al. 2012 Owyhee River intracanyon lava flows: Does the river give a dam?. Geological Society of America Bulletin. 124.

Ishaq R, Hairiah K, Alfian I, Van Noordwijk M 2020 Natural Regeneration After Volcanic Eruptions: Resilience of the Non-legume Nitrogen-Fixing Tree Parasponia rigida. Frontiers in Forests and Global Change. 3. 562303.

Kilburn, CRJ 2000 Lava flows and flow fields. In: Sigurdsson, H (Editor-in-Chief). Encyclopedia of Volcanoes, p. 291-305. Academic Press, San Diego.

Magnusson B, Magnússon S, Ólafsson E, Sigurdsson B 2014 Plant colonization, succession and ecosystem development on Surtsey with reference to neighbouring islands. Biogeosciences. 11. 5521-5537.

Potgieter L, Wilson J, Strasberg D, Richardson D 2014 Casuarina Invasion Alters Primary Succession on Lava Flows on La Réunion Island. Biotropica. 46.

Thoha AS, Triani H 2021 A spatial model of forest and land fire vulnerability level in the Dairi District, North Sumatra, Indonesia. Biodiversitas 22: 3319-3326.

Tsuyuzaki S 1995 Vegetation recovery patterns in early volcanic succession. J. Plant Res. 108, 241-248.

Utami N, Sapei A, Apip. 2017 Land use change assessment and its demand projection in Batanghari River Basin, Sumatera, Indonesia. Limnotek 24 (2): 52-60.

Whittaker RJ, Bush MB, Richards K 1989 Plant recolonization and vegetation succession on the Krakatau islands, Indonesia. Ecological Monographs 59(2): 59-123. 